\title{
THE USE OF PUBLIC FINANCIAL SUPPORT: STUDY OF MICRO-ENTERPRISES
}

Ilona Beizitere ${ }^{1}$, Mg.oec./Researcher; Ieva Brence ${ }^{2}$, Dr.sc.admin./Assoc.prof. ${ }^{1}$ Saeima of the Republic of Latvia; ${ }^{1,2}$ RISEBA University of Applied Sciences

\begin{abstract}
At times when businesses are expected to contribute to economic growth, the topic of access to finance remains relevant. The study investigates the availability of public financial support for micro-enterprises which similarly to the European average is the largest enterprise category in Latvia (about 94\%). In an ad hoc survey of the companies registered in Latvia in nationally defined sectors, entrepreneurs disclosed their sources of funding over the three-year period of 2015-2017. Valid responses from 2511 companies, of which 1879 were micro-enterprises, revealed not only the diversity of their financial sources but also funding conditions impracticable to companies. According to the data processed by SPSS, micro-enterprises still prefer bank financing (11\%) among many sources, whereas only $4 \%$ of the respondents used loans supported by public funding. Surprisingly, while almost half of the micro-enterprises required new or additional funding, a large number relied solely on internal finance. Rejections were frequent not only from banks, but also from the institution providing for public financial support.
\end{abstract}

Key words: banks, finance institutions, micro-enterprises, public financing

JEL code: G21, G23, G28, L29

\section{Introduction}

The European Commission set up the framework for public financial support to improve access to finance for SMEs, in acknowledgment of the dependence of economic success in Europe on the growth of small and medium-sized enterprises (SMEs). Micro-enterprises (MEs) (i.e., enterprises with fewer than 10 employees and a turnover or a balance sheet total below $2 \mathrm{M}$ euros, as defined by the European classification system) are the most common type of non-financial companies in the European Union (EU). They represent $93 \%$ of all European businesses and employ 30 \% of EU workers. (Kraemer-Eis H. et al., 2019). MEs also form the largest share of companies in Latvia, where they account for $94 \%$ of all the economically active enterprises (Central Statistical Bureau..., 2019). Their role in Latvian economy is comparatively higher than on average across the EU, with a business turnover of $26 \%$ against the EU average of $17 \%$ (Ministry of Economics..., 2019b). Previous studies have shown improved access to finance as the most effective way of removing the barriers for company growth (e.g. Beck T. and Demirgüç-Kunt A., 2006). Therefore, our focus in the present study is availability of finance to MEs.

A survey by the European Central Bank reports that access to finance largely remains a problem for the European MEs as compared to companies of other size classes, with $9 \%$ of MEs reporting it as their biggest problem in 2019 (compared to $6 \%$ in the small company, $7 \%$ in the medium-sized and $5 \%$ in the large company segments respectively). This is an improvement since 2014 when $15 \%$ of the MEs reported it as their most essential problem. Meanwhile, only $5 \%$ of the MEs reported improved access to external funding, especially bank loans, compared to the past 6 months (European Central Bank, 2019).

An ad hoc online survey (WAPI) was conducted among the businesses registered in Latvia to establish the financial sources predominantly used by the entrepreneurs, the grounds on which their requests were turned down. The survey sought to establish how prevalent was the problem of accessing external funding among companies, depending on their size and regional location. A second aspect in the context of the assessment was availability of public funding to MEs in the situation of

\footnotetext{
${ }^{1}$ Ilona Beizitere: e-mail: ilona.beizitere@gmail.com

2 Ieva Brence: e-mail: ieva.brence@riseba.Iv
} 
seemingly ample availability of EU funds to Latvian businesses. By looking at the perceptions of businesses of public financial support implemented via the financial offers from the joint stock company "Development Finance Institution Altum" (ALTUM), we have attempted to highlight the differences between the ambitions of MEs to access finance, including public financial support, and the practical obstacles encountered.

A computer assisted web interviewing (CAWI) questionnaire was sent out to all companies with publicly available e-mail addresses in the period between October 1, 2017 and January 25, 2018. The request to fill out the questionnaire was addressed to the person responsible for the company's finances. The target population included all companies across the territory of Latvia with activities in sectors eligible for public support. The entire segment studied included all the active businesses registered in the Latvian Enterprise Register with the 11 defined NACE codes, i.e. 32308 companies in total. For improved representativeness data were weighed by the share of the sector. Responses from 2511 companies were considered valid, from them 1879 responses came from MEs. Businesses were invited to reveal their financial sources over the period of three years: from 2015 to 2017. The results regarding the sources of financing that the Latvian MEs chose or declined to use and the grounds for making the choice were comparable to the average European context, as perceived by the MEs of EU. This suggests that despite the policy measures established for improving access to public finance, including for the MEs, there have been few targeted actions for making these measures work, and the proposals drafted may be delayed.

\section{Micro enterprises financing - theoretical aspects}

The issue of access to finance for MEs with respect to available public support has not been a topic widely studied. Therefore, the literature review includes sources with conclusions on accessibility of finance also for other businesses, when they are relevant for MEs. A range of authors have studied small companies without specifically singling out the ME category. More attention has been given to the description of the smallest businesses, as well as start-up companies. Since newly established companies are predominantly small and do not exceed the size of MEs, conclusions on start-ups have also been included. For example, Brown R. and Lee N. (2017) acknowledge that small firms are different from big firms, and these features have significant ramifications for their ability to obtain finance and the problems related to poor access to financing seem particularly acute for the smallest firms and new start-ups.

Several authors (e.g. Hall G. et al., 2000; Beck T. and Demirgüç-Kunt A., 2006; Beck T. et al., 2008; Moritz A. et al., 2016) have stressed in their studies the importance of company size in accessing finance, stating that small businesses are more restricted in this area than larger companies. They also emphasize the importance of financial institutions that may provide for appropriate funding and enable access.

The World Bank research (Schiffer M., Weder B., 2001) may have been the first instance when size of the company and differences in company size have been highlighted as a barrier to their development. Even though MEs were not singled out within the small company group, the research drew an conclusion that smaller firms faced significantly more problems with financing than larger firms. Thus, one of the main goals in developing support policies for the MEs with a view of setting a level playing ground for competition between companies is to find a way how to mitigate the consequences of this difference. 
However, only EIF researchers (Masiak C. et al., 2017a) in a survey of EU Member State companies (notably, in the context of the SME definition developed in EU) reported, that MEs differed from small and medium-sized companies in their sourcing patterns. Results reveal that micro firms are more likely to use internal financial sources. Also, micro firms appear less likely to be funded by subsidised loans or grants, even though they are often targeted by specific support programmes.

Despite the substantial measures undertaken by authorities to increase financial support, it is found that small businesses, particularly start-ups, face many obstacles (Ruchkina G. et al., 2017; Klein M. et al., 2020). The most recent data show that MEs are less active in using external financial instruments than their larger peers, the reason possibly posed by difficulties in accessing them. The survey (European Central Bank, 2019) has determined that bank loans are used by $18.9 \%$ of the small companies and by $25.3 \%$ of the medium companies, while the share of MEs that use bank loans is as low as $11.6 \%$. Notably, almost half of the MEs indicated that bank loans were a relevant source of funding, the percentage by far exceeding the rate at which they themselves used the source.

The survey SAFE (Kwaak T. et al., 2019) states that the bank loan rejection rate is still highest among MEs (10.8\%), compared to $5.8 \%$ among small firms and $3.1 \%$ among medium-sized firms. Consequently, the share of MEs that failed to apply for a loan due to fear of being rejected (discouraged borrowers) remains high at $5.7 \%$. Among the MEs, $54 \%$ said they did not use bank loans because they were not a relevant source of funding for them. The SAFE survey concluded that frequent reasons for avoiding bank loans among MEs were: insufficient collateral, high interest rates and excessive paperwork. Rejected or discouraged customers often turned to an alternative solution.

When developing public support in the form of financial instruments (FIs) designed by EU funds to overcome "market failures" it is important to be aware that "not all SMEs are the same" (Cassar G., 2004). The author draws attention to the financial problems particularly acute for the smallest firms. The results of the study (Masiak C. et al., 2017b) show that the funding sources of SMEs depend on the type of business, industry and other characteristics of the company. The public support-based FIs seem to be used less often by micro firms than by larger-size companies. The MEs covered within their study also depended on internal funding to a higher extent. The motivation was that there was little clarity about the specific nature of the public support developed: such support either did not meet the requirements of the MEs or, else, the MEs were not aware of the government support provided via the FIs, despite of the fact that the programmes were specially designed to facilitate access to finance.

\section{Research results and discussion 1. Results}

A company survey was carried out in early 2018 to establish the options of MEs in Latvia for obtaining funding and the potential sources. The aim of the survey was to find out the funding needs in strategically important sectors, the importance of "access to finance", the preferences of companies when choosing the sources and the extent to which MEs sought for public support and obtained it. The survey data processing, reability tests (Table 1), Kolmogorov-Smirnov Test (Table 2) have been done by the programme in the SPSS environment. 
Data reability tests by SPSS

\begin{tabular}{|c|c|c|c|c|c|}
\hline \multicolumn{4}{|c|}{ Case Processing Summary } & \multicolumn{2}{|c|}{ Reliability Statistics } \\
\hline & & $\mathrm{N}$ & $\%$ & Cronbach's Alpha & $\mathbf{N}$ of Items \\
\hline \multirow{3}{*}{ Cases } & Valid & 1879 & 100,0 & \multirow{3}{*}{,823 } & \multirow{3}{*}{13} \\
\hline & Excludeda & 0 & 0 & & \\
\hline & Total & 1879 & 100,0 & & \\
\hline
\end{tabular}

a. Listwise deletion based on all variables in the procedure.

One-Sample Kolmogorov-Smirnov Test

\begin{tabular}{|l|l|c|c|}
\hline \multicolumn{2}{|c|}{} & ID & Access to finance \\
\hline $\mathbf{N}$ & Mean & 1879 & 1879 \\
\cline { 2 - 4 } Normal Parametersa,b & Std. Deviation & 1567,49 & 2,94 \\
\hline \multirow{3}{*}{ Most Extreme Differences } & Absolute & 927,600 & 1,406 \\
\cline { 2 - 4 } & Positive &, 065 &, 139 \\
\cline { 2 - 4 } & Negative &, 065 &, 139 \\
\hline Kolmogorov-Smirnov Z &,- 051 &,- 132 \\
\hline Asymp. Sig. (2-tailed) & 2,812 & 6,011 \\
\hline
\end{tabular}

a. Test distribution is Normal.

b. Calculated from data.

The survey data have been analysed from a regional perspective according to the legal address of the companies: separate for Riga and the 5 statistic regions of Latvia.

In response to the question "What types of financing does the company use now or in 20152017 ?", 64 \% of a total of 1869 MEs indicated that they relied solely on internal financing (loans from the owner, relatives, friends or related companies, proprietary investment in fixed assets, or undivided profits). The highest share of MEs that relied solely on internal funding was in Riga (69 $\%$ ), whereas the lowest share was in Latgale (43\%) (Figure 1).



Source: authors' calculations

Fig. 1. MEs relying solely on internal funding $2015-2017$, breakdown by region $(n=1201)$

The survey allowed MEs to indicate more than one source of financing. Among the prevailing sources of external financing mentioned by the rest of the MEs were: ALTUM loans - $4 \%$, EU funds - $6 \%$, bank loans guaranteed by ALTUM - $3 \%$, long-term or short-term bank loans, credit line, overdraft - $11 \%$, lease financing - $13 \%$ and supplier or contractor debt - $10 \%$. Other sources appeared rarely, e.g. only 10 MEs (all of them located in Riga) mentioned venture capital funds and business angel funds. 

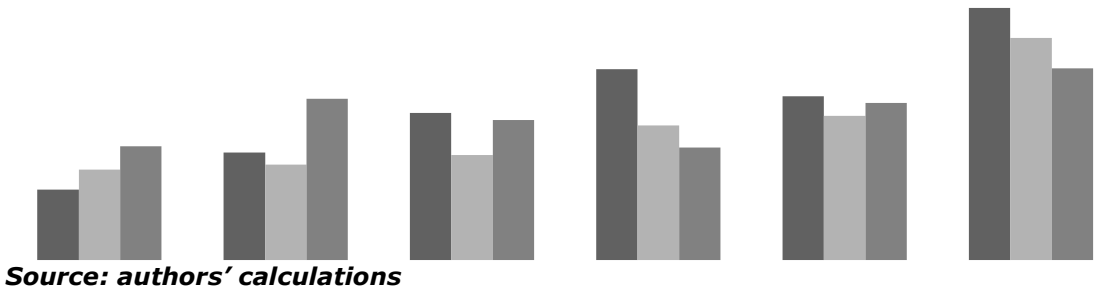

u Public support-based financing

Banks' long-term or short-term financing

- Leasing company financing

Fig. 2. The prevalent funding sources in $2015-2017$, breakdown by region $(n=678)$

Leasing companies were more commonly mentioned by companies in Riga and the Riga region. Alternatively, public support-based financing (bank loans guaranteed by ALTUM, ALTUM loans, incl. mezzanine and EU fund- based financing) appeared to be in comparatively high demand in all regions (excluding Riga) (Figure 2). Public financial support has been more widely used in the Latgale and Kurzeme regions, whereas the total amount of external funding consumed has been highest in Latgale.

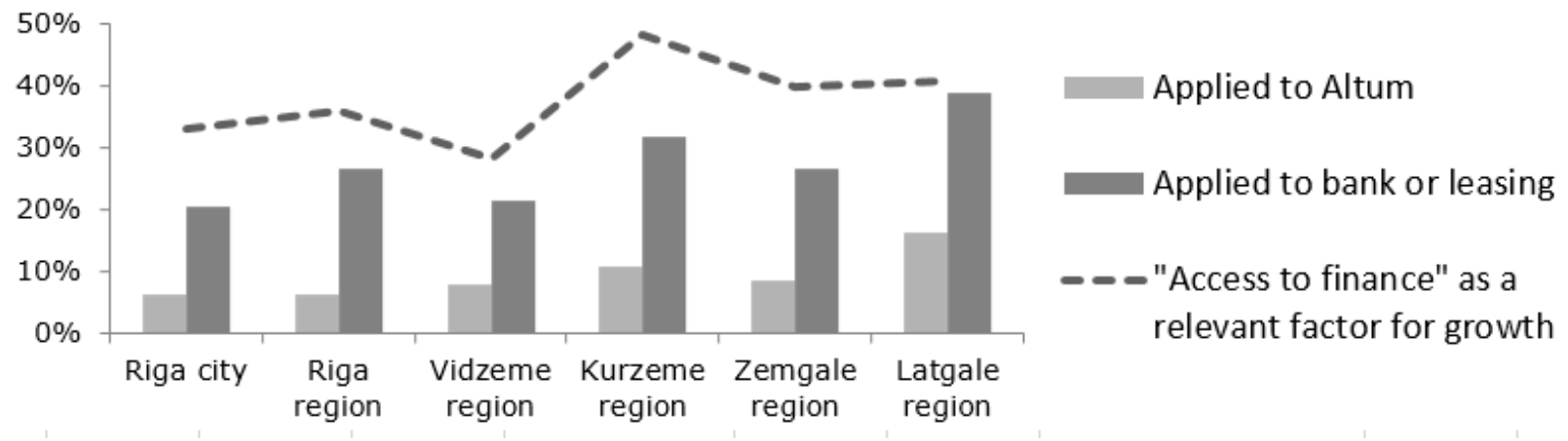

Source: authors' calculations

Fig. 3. The share of MEs that indicated "access to finance" as a relevant factor, and the share of MEs that addressed their financing needs to ALTUM, the banks or leasing companies in 2015 - 2017, breakdown by region $(n=1879)$

Out of the surveyed MEs, $49 \%$ indicated new or additional finance needs in 2015-2017, whereas in Kurzeme and Latgale the percentage was even higher - at $60 \%$. About $35 \%$ pointed out that "access to finance" was relevant for company growth. This was particularly emphasized by the MEs of Kurzeme and Latgale. On the other hand, only a small part of MEs applied for funding to ALTUM irrespectively of the region of their location (Figure 3).

From the companies that addressed their funding needs to ALTUM, 55 MEs (or $39 \%$ ) were rejected (Figure 4). Only every $4^{\text {th }}$ applicant obtained the full amount of funding requested. 26 MEs (or $18 \%$ ) did not accept ALTUMS's offer, pointing to complicated application review procedures, the high number of documents required, high collateral requirements and the overall price of the loan.
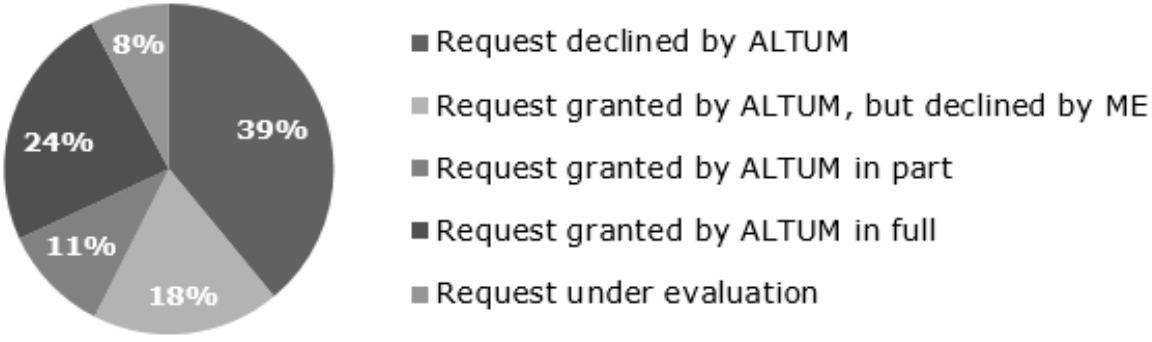

Source: authors' calculations

Fig. 4. Outcomes for the MEs that addressed their funding needs to ALTUM 2015 - 2017 $(n=141)$

The question of why the ME did not consider applying to ALTUM for funding was answered by $31 \%$ of the respondents. Notably $53 \%$ indicated that they lacked knowledge about the funding 
possibilities offered by ALTUM, whereas $19 \%$ thought that ALTUM would not support their financial needs (Figure 5).

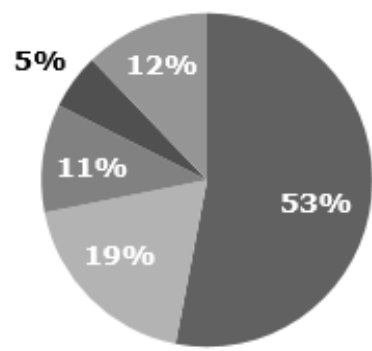

Source: authors' calculations
- No/insufficient knowledge about ALTUM's offer

n Disbelief that ALTUM would provide for the required funding

- Better sources of funding available

- Other reasons

- Hard to say

Fig. 5. Grounds for the MEs to address their funding needs to ALTUM 2015-2017 ( $n=590)$

\section{Discussion}

European Commission works on improving access to finance for SMEs. A range of FIs providing for state aid have been developed to offer alternative financial products instead of traditional debt financing. FIs are measures of financial support provided on a complementary basis from the budget in order to address specific policy objectives of the EU in the form of equity or quasi-equity investments, loans or guarantees and other risk-sharing instruments (Regulation (EU, Euratom)..., 2018). Notably, not all of them are suitable to all companies. As such, they should be adapted to businesses regarding company size, risk level, business cycle and other criteria. There is a lot of imbalance in the development and use of alternative FIs across Member States (OECD, 2018).

From the 4.4 B EUR planned for entrepreneurial support in the multi-annual financial framework of 2014-2020 in the priority "Competitiveness of small and medium enterprises", the amount allocated to Latvia was 334.3 M euros (Ministry of Economics..., 2019a). After deducting the share of the intermediaries, the amount available to the final beneficiaries (commercial companies) through FIs in the financial institution ALTUM and the accelerator and venture capital funds has been 162.46 $M$ euros. Essentially, EU grants funding in the form of state aid for every Member State on the condition that it will be solely used to target market failure. The progress report on implementation of FI programs has established that despite the measures to ensure SME access to finance in the Latvian financial market, market failure persists (Ministry of Economics..., 2017). The report recommended maintaining ALTUM's interventions in funding the small businesses, given the differences in the lending policies and financing conditions of ALTUM and the commercial banking sector. In turn, the Board Chairman of the Association of Regional Development Centres (ARDC) has voiced an opinion that state support, for example, the FIs offered by ALTUM, tends to be too selective, and the conditions for support programmes do not consider the dimension of regional development (Krauklis V. A., 2019).

In their final evaluation of the contribution of the EU funds for business support in the 2007 2013 programming period in Latvia, the authors (Ernst\&Young Baltic, 2018) concluded that the impact on business development has been insufficient to address regional development problems. Among the ME programmes focussing on their support, the one highlighted was "Aid for Investment in Micro, Small and Medium-Sized Companies in Assisted Areas", which is no more on offer.

Some studies on Latvian MEs show that barriers in access to finance persist. A survey (Vanags J. et al., 2018) conducted among 103 Latvian entrepreneurs in the cross border area of Latvia and Lithuania and covering $68.6 \%$ of the Latvian MEs showed that the majority of both new and existing companies perceived that there was a need for public support in the form of loans, grants and other 
support instruments. They saw the need for specific programmes to assist companies operating in the regions.

Latvia is one of the few countries that has developed a separate law for public support of innovative start-ups that might be rapidly developed to a global scale. In 2019 there were more than 400 start-ups that complied with the criteria in the legislation; however, in early 2020 only 6 of them obtained support from the state financing programme (Investment and Development Agency..., 2020). Yet, the study (GatewayBaltic, 2019) found that several start-ups were needed a loan for development but had been prevented from turning to ALTUM on account of the private guarantee requirement for securing the loan. Such requirements are, in fact, inappropriate in the initial stage of a business when the success of the business is still under question. Meanwhile, several start-ups stated that they had gained some external funding: in $30 \%$ of the cases the source has been "business angels", in $18 \%$ - acceleration funds, in $18 \%$ - venture capital funds, in $12 \%$ - loans for starting a business, whereas $7 \%$ indicated that they had made use of a grant for start-up activities and $2 \%$ had benefited from crowdsourcing activities. This study on start-ups concluded that the initial goal for supporting them has become outdated.

Notably, ALTUM offers programmes on favourable conditions providing a solution for many MEs as an alternative to loans. A research conducted by ALTUM found that within the next few years business development in Latvia, micro businesses included, might require about $7 \mathrm{~B}$ euros (Firmas.Iv, LETA, 2018). ALTUM covers about $40 \%$ of the amount that might potentially be required for business support. Also, most of the businesses do not even apply for the support. If all the companies rejected by banks turned to ALTUM with their financial needs, the number of loans could be doubled.

The most recent survey (ALTUM, 2020) among more than 300 new entrepreneurs in Latvia who have started a new business or business project over the past 3 years established that the majority or $85 \%$ of the entrepreneurs initially sourced it from internal funding, which is more than the share of $76 \%$ recorded in 2017. The surveyed entrepreneurs also indicated (as compared to 2017) that they had sourced their business from: partner capital - $21 \%(14 \%)$, family savings $-16 \%(20 \%)$, family loan $-8 \%(5 \%)$, private loan $-12 \%(8 \%)$, national, EU or organizational level support programmes $-10 \%(13 \%)$, bank loans - $8 \%$ (9\%). Even though the surveyed entrepreneurs perceived ALTUM as the most popular institutional financing source, they also indicated their perception that there would be less available funds in the coming year.

\section{Conclusions and recommendations}

In circumstances when Latvia has enough funds for EU granted state aid, availability of public support-based funding remains a challenge for many MEs in Latvia. A survey of Latvian companies active in the strategically important sectors has led to the following conclusions:

1) Even though about half of the MEs need finance, they are more likely to rely solely on internal rather than external funding.

2) Public support-based funding is not a popular choice among MEs for sourcing company growth.

3) MEs do not make full use of public support-based financing instruments. There is a diverse offer of such FIs, and ALTUM as the principal intermediary has enough capacity to offer support to a much larger number of MEs than it presently does.

4) MEs may be experiencing difficulties in obtaining public support in the form of different FIs. They are likely to be caused by lack of knowledge or awareness of the options for obtaining the required 
funding through ALTUM. The MEs feel insecure, discouraged and lack assurance in addressing their needs to ALTUM.

For meaningful public support-based FIs targeting micro-businesses, policy makers should consider the following:

1) The offer addressed to MEs should differ from the offer to larger size companies. In practice, the state aid programmes helpful for most SMEs are not always well-adapted to MEs.

2) Access to finance is complicated by the differences between MEs (incl. in their business cycle, geographical location). Local and regional factors also have an impact on demand.

3) Previous experience in the uptake of EU funds would be a useful resource for developing and improving the support programmes and financing instruments already recognized for their value and demanded by companies. Also, the support instruments should be adapted to the current needs of MEs in a timely way.

A focussed financial offer for the MEs in Latvia should draw on in-depth studies of causalities, the current needs of MEs and the reasons why MEs choose or avoid applying for external funding in the form of public support-based financial instruments.

\section{Bibliography}

1. ALTUM (2020). Biznesa uzsaceju petijums 2020.02.25 (Business Startups Study 2020.02.25). Retrieved: https://www.slideshare.net/ALTUMlv/biznesa-uzsaceju-ptjums-20200225. Access: 01.03.2020.

2. Beck, T., Demirgüç-Kunt, A. (2006) Small and Medium-Size Enterprises: Access to Finance as a Growth Constraint. Journal of Banking \& Finance, Volume 30, Issue 11, November 2006, pp. 2931-2943.

3. Beck, T., Demirgüç-Kunt, A. and Maksimovic, V. (2008) Financing Patterns Around the World: are Small Firms Different?, Journal of Financial Economics, Volume 89, Issue 3, September 2008, pp. 467-487.

4. Brown, R., Lee, N. (2017). The Theory and Practice of Financial Instruments for Small and Medium-Sized Entreprises. EC-OECD Seminar Series on Designing better economic development policies for regions and cities. OECD. 28 June 2017. Retrieved: https://www.oecd.org/cfe/regional-policy/Brown_When-to-usefinancial-instruments.pdf. Access: 20.01.2020.

5. Cassar, G. (2004). The financing of business start-ups. Journal of Business Venturing, Volume 19, Issue 2, March 2004, pp. 261-283

6. Central Statistical Bureau of Latvia (2019). SRG030. Economically Active Enterprises of Market Sector in Statistical Regions, Cities and Counties by Size Group According to the Number of Employees and Main $\begin{array}{llll}\text { Economic Activity } & \text { Rev. } & \text { 2). } & \text { Retrieved: }\end{array}$ http://data1.csb.gov.Iv/pxweb/en/uzn/uzn_01_skaits/?rxid=d8284c56-0641-451c-8b70b6297b58f464\&tablelist=true. Access: 18.12 .2019 .

7. Ernst\&Young Baltic, Ltd. (2018). Contribution and Impact of EU Support to Entrepreneurship in the $2007-$ 2013 Period. Evaluation Final Report (LV). (Original title: Nosleguma izvertejums: Eiropas Savienības fondu ieguldījumu izvertesana uznemejdarbibas atbalstam 2007. - 2013. gada planosanas perioda un so ieguldījumu ietekmes noteiksana). Latvijas Republikas Finanšu ministrija, 06.07.2018. Retrieved: https://ec.europa.eu/regional_policy/en/policy/evaluations/member-states/. Access: 09.02.2020.

8. European Central Bank (2019). Survey on the Access to Finance of Enterprises in the Euro Area. April to September 2019. 2019.2 Rovember 20 Retrieved: https://www.ecb.europa.eu/stats/ecb_surveys/safe/html/index.en.html. Access: 30.01.2020.

9. Firmas.Iv, LETA (2018). Latvijas biznesa gada parskats 2018 (Latvian Business Annual Report 2018), pp. 3233. Firmas.Iv. Retrieved: https://www.firmas.Iv/files/lbgp/2018/LBGP_2018.pdf. Access: 28.11.2019.

10. GatewayBaltic, Ltd. (2019). Latvijas jaunuznemumu ekosistemas novertesana, pasreizeja stavokla identificasana un uz tas balstitu priekslikumu izstrade (Assessing the Ecosystem of Start-ups in Latvia, Identification of the Current Situation and Development of Proposals), id.nr. EM 2018/58, Ekonomikas ministrija, 08.02.2019. Retrieved: https://www.em.gov.lv/files/attachments/2019-0327_11_46_18_Jaunuznemumu_petijums.pdf. Access: 16.02.2020.

11. Hall, G. C., Hutchinson, P. J., Michaelas, N. (2000). Industry Effects on the Determinants of Unquoted SMEs' Capital Structure. International Journal of the Economics of Business. Volume 7 (3): pp. 297-312.

12. Investment and Development Agency of Latvia (2020). Atbalstito jaunuznemumu registrs (Register of supported start-ups). Retrieved: http://www.liaa.gov.Iv/lv/fondi/2014-2020/jaunuznemumu-atbalstaprogrammas/atbalstito-jaunuznemumu-registrs. Access: 29.02.2020.

13. Klein, M., Neitzert, F., Hartmann-Wendels, T., Kraus, S. (2020). Start-up Financing in the Digital Age-A Systematic Review and Comparison of New Forms of Financing. The Journal of Entrepreneurial Finance. Volume 22, No. 1 (Spring 2020), pp. 1-26. 
14. Kraemer-Eis, H., Botsari, A., Gvetadze, S., Lang, F., Torfs, W. (2019). European Small Business Finance Outlook: December 2019 (Working Paper 2019/061). EIF Research \& Market Analysis. Retrieved: https://www.eif.org/news_centre/publications/EIF_Working_Paper_2019_61.htm. Access: 18.02.2020.

15. Krauklis, V. A. (2019). Vai Nacionalais attīstības plans veicinas attistbu vai depopulaciju? (Will the National Development Plan Promote Development or Depopulation?). RACA. 01.02.2019. Retrieved: http://raca.Iv/vainacionalais-attistibas-plans-veicinas-attistibu-vai-depopulaciju/. Access: 19.12.2019.

16. Kwaak, T., Cheikh, N., de Kok, J., Kruithof, B., Snijders, J., Stoilova, V. (2019). Survey on the Access to Finance of Enterprises (SAFE). Analytical Report 2019. November 2019. European Commission. Retrieved: https://ec.europa.eu/growth/access-to-finance/data-surveys. Access: 18.12.2019.

17. Masiak, C., Block, J.H., Moritz, A., Lang, F. and Kraemer-Eis, H. (2017a), Financing Micro Firms in Europe: An Empirical Analysis. Working Paper 2017/44, EIF Research \& Market Analysis. Retrieved: http://www.eif.org/news_centre/publications/eif_wp_44.pdf. Access: 18.12.2019.

18. Masiak, C., Moritz, A., Lang, F. (2017b). Financing Patterns of European SMEs Revisited: An Updated Empirical Taxonomy and Determinants of SME Financing Clusters. Working Paper 2017/40, EIF Research \& Market Analysis. Retrieved: http://www.eif.org/news_centre/research/index.htm. Access: 18.12.2019.

19. Moritz, A., Block, J. H., Heinz, A. (2016). Financing Patterns of European SMEs - an Empirical Taxonomy. Venture Capital, Volume 18, Issue 2, pp. 115-148.

20. Ministry of Economics of the Republic of Latvia (2017). An Updated Market Gap Assessment in the Field of Financial Accessibility: Progress Report on Implementation of Financial Instrument Programs. Riga, 2017. Retrieved: https://www.em.gov.Iv/files/es_fondi/MoE_Market_gap_assessment_specified_26102017.pdf. Access: 15.11.2019.

21. Ministry of Economics of the Republic of Latvia (2019a). Atbalsta pasākumi 2014-2020 (Support Measures for 2014-2020). 04.03.2019. Retrieved: https://www.em.gov.Iv/lv/es_fondi/atbalsta_pasakumi_2014_2020/. Access: 18.12 .2020$.

22. Ministry of Economics of the Republic of Latvia (2019b). Norvegijas finansu instrumenta lidzfinansetas programmas "Uznemejdarbibas attistiba, inovacijas un mazie un videjie uznemumi" koncepcijas projects (Concept Project of the Norwegian Financial Instrument Co-financed Program "Entrepreneurship Development, Innovation and Small and Medium Enterprises"). Retrieved: http://tap.mk.gov.lv/lv/mk/tap/?pid=40476439\&mode=mk\&date=2019-08-27. Access: 18.12.2019.

23. OECD (2018). Enhancing SME Access to Diversified financing Instruments. Discussion Paper, SME Ministerial Conference, 22-23 $2018 . \quad$ February Mexico City. https://www.oecd.org/cfe/smes/ministerial/documents/2018-SME-Ministerial-Conference-Plenary-Session2.pdf. Access: 20.10.2019.

24. Regulation (EU, Euratom) 2018/1046 of the European Parliament and of the Council of 18 July 2018 on the financial rules applicable to the general budget of the Union, amending Regulations (EU) No 1296/2013, (EU) No 1301/2013, (EU) No 1303/2013, (EU) No 1304/2013, (EU) No 1309/2013, (EU) No 1316/2013, (EU) No 223/2014, (EU) No 283/2014, and Decision No 541/2014/EU and repealing Regulation (EU, Euratom) No 966/2012. Official Journal of the European Union, L 193/1, 30.7.2018, pp. 1-222.

25. Ruchkina, G., Melnichuk, M., Frumina, S., Mentel, G. (2017). Small and Medium Enterprises in Regional Development and Innovations. Journal of International Studies, Vol. 10, No. 4, pp. 259-271.

26. Schiffer, M., Weder, B. (2001). Firm Size and the Business Environment: Worldwide Survey Results. International Finance Corporation. Discussion paper no. IFD 43. August 2001. The World Bank. Retrieved: http://documents.worldbank.org/curated/en/574601468739143195/Firm-size-and-the-businessenvironment-worldwide-survey-results. Access: 15.01.2020.

27. Vanags, J., Linde, N.., Rivža, B., Sūnina, L. (2018). Petijums par uznemejdarbības atbalsta sistemas ieviesanas iespejam Latvija un Lietuva (Study on Business Support System Implementation Possibilities in Latvia and Lithuania). Latvijas Zinatnu akademijas Ekonomikas instituts, Rīga, 2018. Retrieved: https://www.zemgale.Iv/informativie-materiali/category/21-petijumi?download=408:petijums-paruznemejdarbibas-atbalsta-pieejamibu-zemgale-kurzeme-un-ziemellietuva. Access: 14.01.2020. 